\title{
Re-expression of SPR1 in Breast Cancer Cells by Phorbol 12-Myristate 13-Acetate (PMA) or UV Irradiation Is Mediated by the AP-1 Binding Site in the SPRI Promoter
}

\author{
Anthony Anisowicz, ${ }^{1}$ Georgia Sotiropoulou, ${ }^{2}$ and Ruth Sager ${ }^{1}$ \\ ${ }^{1}$ Division of Cancer Genetics, Dana-Farber Cancer Institute, Harvard \\ Medical School, Boston, Massachusetts, U.S.A. \\ ${ }^{2}$ Department of Pharmacy, School of Health Sciences, University of \\ Patras, Patras, Greece \\ Communicated by A. G. Papavassiliou. Accepted June 18, 1999.
}

\begin{abstract}
Background: Invasive tumor cells are characterized by multiple phenotypic changes as a result of the large number of cDNAs being differentially expressed in tumor cells compared to normal progenitors. Expression genetics focuses on changes at the RNA level with the aim of identifying functionally important genes whose aberrant expression in cancer cells is regulated at the level of transcription. These genes were named class II genes and are distinguished from class I genes, which are characterized by genomic mutations, deletions, or other alterations. Reversal of the tumor cell phenotype accompanying normalization of the expression of such genes may be exploited therapeutically if gene expression can be specifically modulated by drugs or other treatments. Considering that genes are coordinately regulated in complex networks, it is likely that the expression of multiple genes can be simultaneously modulated in tumor cells by drugs acting on the signal transduction pathway that regulates their expression. The SPRI gene is associated with differentiation and its expression is down-regulated or inactivated in malignant cells. Analysis of the SPRI promoter showed that down-regulation of SPRI expression in breast tumor cells occurs at the level of transcription. SPRI presents an example of class II genes, since its expression was up-regulated in tumor cells by phorbol 12-myristate 13-acetate (PMA) or by ultraviolet (UV) irradiation.

Materials and Methods: The SPRl gene was identified by differential display on the basis of its reduced or absent expression in human breast tumor cell lines compared to normal mammary epithelial cell strains. Differential expression was confirmed by Northern blot analysis employing multiple normal and tumor cell lines. The promoter region -619 to +15 of the SPRI gene was sequenced and analyzed by CAT assays, deletion analysis, and mutagenesis. Up-regulation of SPRI expression
\end{abstract}

by PMA and UV irradiation was monitored by Northern analysis and analyzed by CAT assays.

Results: The mechanism of down-regulation of SPR1 expression in breast tumor cells was investigated. It was found that the -619 to +15 upstream promoter region is sufficient for $S P R I$ expression in normal breast cells, but it is transcriptionally silent in most breast tumor cell lines. By deletion analysis and mutagenesis, two upstream cis-acting promoter elements were identified. Our data indicate that the AP-1 element located between -139 and -133 acts as a major enhancer of SPRI transcription only in normal mammary epithelial cells but not in corresponding tumor cells, whereas the sequences flanking the AP-1 site do not affect its promoter enhancing activity. In addition, a transcriptional repressor was identified that binds unknown factor(s) and is active in both normal and tumor breast cells. Inhibitor function was mapped to a 35-bp element located from -178 to -139 upstream of the human SPRI mRNA start site. The expression of SPRI could be induced in the 21MT-2 metastatic breast tumor cell line by PMA treatment or by short UV irradiation via a transcriptional mechanism. $\mathrm{AP}-1$ is the cis element mediating the transcriptional activation of SPRI by PMA, which induces the expression of AP-1 factors in 21MT-2 cells. Mutation of the AP-1 site abolishes the induction of SPRI expression by PMA.

Conclusions: Our results demonstrate that loss of SPR1 expression in breast tumor cells results from impaired transactivation through the AP- 1 site in the SPRI promoter, as well as from the presence of a negative regulatory element active in both normal and tumor cells. Furthermore, our results provide a basis for therapeutic manipulation of down-regulated genes, such as $S P R I$, in human cancers. 


\section{Introduction}

The novel concept of RNA genetics in cancer underscores the importance of changes in the expression of critical genes in understanding and treating cancer (1). Instead of studying mutations or other gene alterations at the genome level, expression genetics focuses on changes at the RNA level. We have previously applied methods of differential expression cloning, such as subtractive hybridization (2) and differential display (DD) $(3,4)$, to the identification of genes whose expression is up- or down-regulated in breast cancers. Several novel genes were identified and their putative functional role(s) in regulating the growth and/or dissemination of mammary tumors was investigated (4-7). Differential display allows the quantitative evaluation of cellular messenger RNA patterns. Comparison of well-matched cell lines showed remarkable similarity in expression profiles of normal and tumor breast cells, while the percentage of differentially expressed messages was only $0.5-1 \%$. Our results indicated that the number of complementary DNAs (cDNAs) differentially expressed between normal and metastatic breast cancer cells lies in the range of 500 to $1000(1,5)$. Similar data were obtained by others who analyzed differential gene expression in human colon cancer by means of serial analysis of gene expression (SAGE) (8). The large number of differentially expressed cDNAs is consistent with the multiple phenotypic changes characteristic of metastatic tumor cells. Functionally important genes, whose aberrant expression in tumor cells is regulated at the level of transcription, can possibly be targeted for therapy if their normal expression can be induced by drugs. Therefore, it is essential to delineate the mechanism(s) underlying the aberrant regulation of transcription of cancerrelated genes. In this report, the small proline-rich protein gene (SPRI) was identified by DD on the basis of its reduced or absent expression in human breast tumor cell lines compared to normal counterparts. Evidence is presented that down-regulation of SPRI in breast tumor cells occurs by a transcriptional mechanism.

Small proline-rich $(S P R)$ proteins are char-

\footnotetext{
This manuscript is written in memory of our mentor and friend, Professor Ruth Sager.

The sequence reported in this manuscript appears in the GenBank $^{\mathrm{TM}} / \mathrm{EMBL}$ database with the accession number AF079516.

Address correspondence and reprint requests to: Dr. Georgia Sotiropoulou, Department of Pharmacy, School of Health Sciences, University of Patras, Rion 26500 , Patras, Greece. Phone: 30-61-997721; Fax: 30-61-997714; E-mail: g.sotiropoulou@upatras.gr
}

acterized by an unusually high content in proline residues and were originally identified in cultured keratinocytes as ultraviolet (UV)-inducible genes $(9,10)$. SPR proteins are rich in cysteine and glutamine residues and contain repeating elements unique to the SPR family. Similarly, the SPRR genes constitute part of the human epidermal differentiation complex and their expression is strictly linked to keratinocyte terminal differentiation (11). Squamous carcinoma cell lines, on the other hand, show significantly lower levels of $S P R R$ expression than normal human keratinocytes (12). The $S P R 1$ protein is a component of the crosslinked envelope that forms during the squamous differentiation process and was suggested as a marker associated with squamous cell differentiation, including the airway epithelium $(13,14)$. Although human normal bronchial epithelial cells express high levels of $S P R 1$, expression of $S P R I$ measured by quantitative reverse transcription-polymerase chain reaction (RT-PCR) was inactivated in malignant human bronchial epithelial cells. Therefore, loss of $S P R I$ gene expression likely contributes to malignant transformation by disrupting mechanisms for terminal squamous differentiation (15). The differential expression of $S P R I$ in breast normal and tumor cell lines described in this report indicates that the SPRI protein could also play a significant role in the mammary epithelium. Therefore, the molecular mechanism(s) underlying the differential transcriptional regulation of $S P R I$ was examined. Analysis of the $S P R I$ promoter showed that in normal human breast cells SPRI transcription is regulated by the coordinated action of two major cis elements: the mammalian activating protein-1 (AP-1) site located at -139 to -133 being the positive regulator and a negative regulator of $S P R 1$ transcription located at -178 to -139 . The $S P R 1$ gene promoter was characterized in a previous study $(16,17)$, which indicated the presence of both phorbol ester and cAMP-responsive elements. We have demonstrated that loss of SPRI expression in breast tumor cells results from the absence of transactivation through the AP-1 binding site in combination with negative regulation through the inhibitory element, and can be restored in 21MT-2 tumor cells by phorbol 12-myristate 13-acetate (PMA) treatment and by UV irradiation. 


\section{Materials and Methods}

\section{Cell Strains, Cell Lines, and Growth Media}

Normal human mammary epithelial cell strains $(81 \mathrm{~N}, 76 \mathrm{~N}$, and $70 \mathrm{~N})$ were derived from reduction mammoplasties. Primary (21NT, 21PT) and metastatic (21MT-1, 21MT-2) tumor cell lines were established from a single patient (18). Metastatic mammary epithelial tumor cell lines MCF7, BT474, BT549, T47D, ZR-75-1, MDAMB-157, MDA-MB-231, MDA-MB-361, MDAMB-435, and MDA-MB-436 were obtained from the American Type Culture Collection (ATCC, Rockville, MD). All cell cultures were routinely grown in DFCl-1 medium (19). Cultures were grown in P100 dishes and harvested at about $75 \%$ confluence for RNA isolation and near confluence for DNA isolation. Escherichia coli $\mathrm{K} 12$ bacteria strain $X L-1$ Blue was obtained from Stratagene (La Jolla, CA). Tissue culture medium components were purchased from Life Technologies (Bethesda, MD) or Hyclone (Logan, UT).

\section{Differential Display}

Total cellular RNAs (50 $\mu \mathrm{g}$ ) from exponentially growing cell cultures were treated with DNase I in the presence of RNasin ribonuclease inhibitor to remove any residual DNA contamination as described elsewhere (4). RNAs were extracted with phenol/chloroform, precipitated with ethanol, and redissolved in DEPC-treated water. Subsequently, the RNAs were reverse transcribed using a $3^{\prime}$-anchored primer $\mathrm{T}_{12} \mathrm{MG}$ (5'-TTTTTTTTTTTTMG-3') (Operon Technologies, Alameda, CA). The resultant cDNAs were amplified by $\mathrm{PCR}$, in the presence of $\left[{ }^{35} \mathrm{~S}\right] \mathrm{dATP}$, using $\mathrm{T}_{12} \mathrm{MG}$ as the $3^{\prime}$-end primer and OPAl (5'-CAGGCCCTTC- $3^{\prime}$ ), an arbitrary 10 -mer primer, as the $5^{\prime}$-end primer and resolved side-by-side on a $6 \%$ acrylamide/urea sequencing gel. The partial cDNA bands were localized by autoradiography and eluted as described elsewhere (4). A differentially displayed cDNA of $\sim 0.16$ kilobases $(\mathrm{kb})$ was recovered from the dried gel, purified by a Millipore Ultrafree MC unit, reamplified by PCR, ${ }^{32}$ P-labeled by the oligolabeling method (20), and used as a probe for hybridization of Northern blots. The partial cDNA obtained from DD was subcloned into the PCRII vector (Invitrogen), and a corresponding full-length cDNA clone was isolated and sequenced on both strands with T7 and SP6 primers. A cDNA library from $76 \mathrm{~N}$ cells constructed in $\lambda$ Zap II (Stratagene, San Diego, CA) was screened using the cloned PCR product as a probe and several full-length cDNA clones were isolated. The differential expression of SPRI was confirmed by Northern hybridizations of the same RNA samples used for DD, as well as RNAs from a number of normal and tumor cell lines, using a full-length probe. Full-length cDNA clones were sequenced on both strands. Sequencing was performed with an $\mathrm{ABI}$ automated sequencer, Model 373A, in the Molecular Biology Core Facility of the Dana-Farber Cancer Institute. The basic local alignment search tool (BLAST) algorithm was used for nucleic acid sequence comparisons (2l).

\section{Northern and Southern Blot Analysis}

Total cellular RNA was isolated from cells cultured to approximately $75 \%$ confluence, purified by standard guanidinium isothiocyanate and cesium chloride centrifugation, and analyzed as described (4). For Northern blotting, $20 \mu \mathrm{g}$ of total RNA was resolved by electrophoresis on $1 \%$ agarose-1.7 $\mathrm{M}$ formaldehyde gels, transferred to a Zetaprobe membrane (BioRad, Richmond, CA) in $20 \times$ SSC solution $(20 \times S S C, 3 \mathrm{M} \mathrm{NaCl}, 0.3 \mathrm{M}$ $\mathrm{Na}_{3}$ citrate, $\mathrm{pH} 7.0$ ), and baked for $1 \mathrm{hr}$ at $80^{\circ} \mathrm{C}$. Hybridizations were performed in formamide at $37^{\circ} \mathrm{C}$ overnight. The blot was washed at $65^{\circ} \mathrm{C}$ for $\mathrm{l} \mathrm{hr}$ in $2 \times$ SSC containing $0.1 \%$ SDS. As an internal loading control, 36B4 was used, a gene encoding a ribosomal protein whose expression is not affected by growth conditions or estrogen receptor expression (22). For Southern blotting, $10 \mu \mathrm{g}$ of genomic DNA was digested with EcoRI overnight at $37^{\circ} \mathrm{C}$, fractionated on a $1.5 \%$ agarose gel, transferred to nylon membrane, and hybridized as above. Genomic DNA was isolated and hybridized by standard methods (23). Densitometric scans of autoradiographs were obtained with the BioRad GS-700 imaging densitometer using Molecular Analyst software.

\section{Isolation of Genomic Clones: Promoter Cloning and} Sequencing

Genomic clones for the SPR1 gene were isolated from a human white female leukocyte $M b o I$ partial library in $\lambda E M B L 3$. Approximately $1 \times 10^{6}$ plaques were screened with a ${ }^{32} \mathrm{P}$-labeled SPR1 full-length cDNA probe. Single hybridizing plaques were isolated after three rounds of screening picked into SM buffer (23) and amplified by PCR $\left(95^{\circ} \mathrm{C}, 1 \mathrm{~min} ; 55^{\circ} \mathrm{C}, 1 \mathrm{~min} ; 72^{\circ} \mathrm{C}, 1\right.$ min; 35 cycles) with -622 and CAP primers (see oligonucleotide section below). Subsequently, 
the $0.63 \mathrm{~kb}$ PCR product was cloned into the PCRII vector (Invitrogen). Plasmid DNA was prepared and digested with HindIII and Sall; the $0.63 \mathrm{~kb}$ promoter fragment was purified on Qiaex (Qiagen, Chatsworth, CA) and cloned into the promoterless chloramphenicol acetyltransferase (CAT) vector pKT (24). The promoter containing plasmid was sequenced at the Dana-Farber Cancer Institute Core Facility with an ABI 373A automated DNA sequencer (Applied Biosystmes, Foster City, CA). Genomic DNA from the $70 \mathrm{~N}$ normal cell strain was similarly amplified by PCR with -622 and CAP primers, cloned into the PCRII vector, and sequenced as above.

\section{Synthetic Oligonucleotides}

For PCR amplification of the SPR I promoter fragment the following oligonucleotides were used: -622-primer (5'-GGTCGACCAGAGTTCACTGCTCCGA-3') and CAP primer (5'-CAAGCTTAGAACTGGTGGTAGTGTTCCC-3') (modified from primer sequences used by $\mathrm{R}$. Wu, personal communication). For construction of the pKT/SPR1 promoter $5^{\prime}$ deletion mutants, the antisense CAP primer $\left(5^{\prime}\right.$-AAGCTTAAGCTTAGAACTGGTGGTAGTGTTCCC-3') was used for PCR in combination with each of the following sense oligonucleotides: for p-224 (5'-GTCGACGTCGACCCTGGAGCAAAGGGTGTTCAG-3'); for p-133 (5'-GTCGACGTCGACAGGTGGGTGAGGGAAGAGGGG-3'). The following oligonucleotides were used for the preparation of CAT constructs: SPRI AP-1 WT sense (5'-TCGACCAAAAGTTGAGTCAACAGGTGT-3') and antisense (5'-CTAGACACCTGTTGACTCAACTTTTGG-3'); AP-1 mut l with two changes in the AP-1 site, sense (5'-TCGACCAAAAGTGGAGTCCACCGGTGT- $\left.3^{\prime}\right)$ and antisense (5'-CTAGACACCTGTGGACTCCACTTTTGG-3'); AP-1 mut2 with seven changes in the AP-1 site: sense (5'-TCGACCAAAAGTGCTCGAGACAGGTGT-3') and antisense $\left(5^{\prime}\right.$-CTAGACACCTGTCTCGAGCACTTTTGG-3'); consensus AP-1 WTl-1 (Promega): sense $\left(5^{\prime}\right.$-TCGACCGCTTGATGAGTCAGCCGGAAT- $\left.3^{\prime}\right)$ and antisense (5'-CTAGATTCCGGCTGACTCATCAAGCGG-3'). Sense AP-1 oligos contained SalI cloning sites (TCGAC) and antisense AP- 1 oligos contained $\mathrm{XbaI}$ (CTAGA) cloning sites. Positions where mutations were introduced are underlined. For the construction of pBLCAT2/AP-1 INH, oligos containing the SPR 1 inhibitor region $(-178$ to -139) were used: sense (5'-AGCTTCCTTGTCAGACAGCAAGTGCCACAAGTTTCAT-
CACAAAAGTG-3') and antisense ( $5^{\prime}$-TCGACACTTTTGTGATGAAACTTGTGGCACTTGCTGTCTGACAAGGA-3'). The inhibitor oligos contained HindIII (AGCTT) and SalI (TCGAC) cloning sites, respectively. The final pBLCAT2/AP-1 INH plasmid contained the inhibitor upstream of the AP-1 sequence ligated upstream of the thymidine kinase (TK) promoter. The presence of AP-1 and the inhibitor was confirmed by sequencing. Oligos were synthesized by Amitof (Boston, MA).

\section{$C A T$ and $\beta$-galactosidase ( $\beta$-Gal) Constructs}

The pBLCAT2 and pBLCAT3 CAT expression plasmids were used to test the activity of the $S P R 1$ promoter. The leukocyte promoter fragment from -619 to +15 was subcloned into the pKT promoterless CAT vector (24) to generate the p-619 construct. A nested series of progressive $5^{\prime}$-deletions were generated from p-619 using either restriction enzyme digestion, ExoIII/S I nuclease treatment, or PCR. P-619 was digested with restriction enzyme, blunt ended with $\mathrm{T} 4$ polymerase, and cut with HindIII (at +15$)$, and the promoter fragment with the appropriate size was purified from the agarose gel on Qiaex and cloned into the pKT vector previously digested with SmaI and HindIII. The following deletions were made in this manner: p-477 (AccI), p-297 (AlwNI), p-178 and p-161 (DrdI), and p-58 (BamHI). The p-139 deletion was generated by digestion of p-619 with XbaI and SstI followed by ExoIII treatment, $\mathrm{Sl}$ nuclease treatment (Promega Biotech, Madison, WI), blunt ending with Klenow, and ligation (Erase-a-base system, Promega). The p-224 and p-133 deletion mutants were generated by PCR, at $95^{\circ} \mathrm{C}$ for $1 \mathrm{~min}, 55^{\circ}$ or $60^{\circ} \mathrm{C}$ for $1 \mathrm{~min}, 72^{\circ} \mathrm{C}$ for $1 \mathrm{~min}$ for 30 cycles, with primers shown in the oligonucleotide section. The $5^{\prime}$ endpoints of all constructs were verified by sequencing with the M13R primer. The pBLCAT2 constructs were prepared by annealing the appropriate AP-1 oligonucleotides as described above and subsequent cloning into pBLCAT2 digested with SalI and XbaI, so that the AP-1 sequences were upstream of the TK promoter. The pBLCAT2/INH AP-1 construct was prepared by annealing the inhibitor oligonucleotides and cloning into pBLCAT2 AP- 1 wt previously digested with HindIII and SalI, so that the inhibitor sequence is just upstream of AP-1. All constructs were sequenced to confirm the expected structure. The $\mathrm{pCMV} \beta$-Gal contained the mouse cytomegalovirus (CMV) promoter up- 
stream of the $\beta$-Gal gene and was constructed previously (25).

\section{DNA Transfection and CAT Assays}

Plasmids were prepared by alkaline lysis and column purified (Qiagen). About $1 \times 10^{6}$ cells were plated per P100 dish and grown to about $75 \%$ confluence. According to the method of Graham and van der Eb (26), $70 \mathrm{~N}$ or $21 \mathrm{MT}-2$ cells were transiently transfected for $4 \mathrm{hr}$ with $20 \mu \mathrm{g}$ of each SPRI/CAT reporter plasmids; $1 \mu \mathrm{g}$ of a CMV-driven $\beta$-Gal expression vector (pCMVCAT) was cotransfected as an internal control for transfection efficiency. The calcium phosphate co-precipitate was then thoroughly washed off, fresh medium [Eagle's Minimal Essential Medium ( $\alpha$-MEM) $/ 0.5 \%$ fetal calf serum (FCS)] was added, and the plates were incubated at $37^{\circ} \mathrm{C}$. Transient transfections of reporter plasmids into MDA-MB-231 and ZR-75-1 cell lines were carried out by the lipofectin method (Gibco, BRL, Gaithersburg, MD) or modified DEAE-Dextran (Promega, Madison, WI). Forty-eight hours after transfection, the cells were washed with phosphate-buffered saline (PBS) and harvested by scraping directly into $350 \mu \mathrm{l}$ of $0.25 \mathrm{M}$ Tris $\cdot \mathrm{HCl}$, pH 7.8, 15\% glycerol. Extracts were prepared by three cycles of freezing in dry ice-ethanol and thawing at $37^{\circ} \mathrm{C}$. Protein concentration was determined by the Bradford assay (BioRad). The $\beta$-Gal activity was determined by using $3 \mathrm{mg} / \mathrm{ml}$ chlorophenol red- $\beta$-D-galactopyranoside as substrate and reading the absorbance at $574 \mathrm{~nm}$ as described previously (27). CAT assays were performed on amounts of extracts giving equal $\beta$-Gal activity for the uninduced controls, in 250 $\mu$ l final volume containing $0.8 \mathrm{mM}$ acetyl CoA and $0.2 \mu \mathrm{Ci}$ of [Dichloroacetyl-1,2- ${ }^{14} \mathrm{C}$ ]-chloramphenicol (DuPont/New England Nuclear, Boston, MA) by the method of Gorman et al. (28). Twenty units of extracts (calculated by $\beta$-Gal activity) were routinely used for each CAT assay, while only 2 units of extract were used for transfection with the pCMVCAT-positive control because of its high activity. Quantitation of acetylated CoA and nonacetylated chloramphenicol was performed by excising the appropriate regions of the silica gel thin-layer chromatography (TLC) plate and counting radioactivity in BioFluor (DuPont, Wilmington, DE).

\section{UV Treatment of Cells}

The $21 \mathrm{MT}-2$ cells were cultured to about $70 \%$ confluence. Before irradiation cells were washed several times with PBS, which was then removed, and cells were irradiated with shortwavelength UV light at the following doses: 0,8 , $17,25,33$, and $42 \mathrm{~J} / \mathrm{M}^{2}$. Dose rates were determined with a UVX radiometer (29). After irradiation fresh growth medium was added and cells were incubated at $37^{\circ} \mathrm{C}$ for 12 or $24 \mathrm{hr}$ before they were harvested for isolation of total cellular RNA. For CAT assays, $21 \mathrm{MT}-2$ cells were transfected with reporter plasmids and cultured for 24 hr before UV irradiation. After UV irradiation, fresh growth medium was added, and cells were incubated at $37^{\circ} \mathrm{C}$ for 9,24 , or $32 \mathrm{hr}$ prior to CAT assays.

\section{PMA Treatment of Cells}

The 21MT-2 cells were treated with PMA (100 $\mathrm{ng} / \mathrm{ml}$ ) at $37^{\circ} \mathrm{C}$ for different times. Total cellular RNA was isolated from cells grown on P100 tissue plates (Falcon, Lincoln Park, NJ) to about $75 \%$ confluence. For CAT assays, 21MT-2 cells were transfected with reporter plasmids and cultured for $24 \mathrm{hr}$ before PMA treatment. After PMA treatment, cells were washed with PBS, fresh growth medium was added, and cells were incubated at $37^{\circ} \mathrm{C}$ for 9 or $30 \mathrm{hr}$ prior to CAT assays.

\section{Results}

Identification of SPR 1 by Differential Display

Total RNAs from $76 \mathrm{~N}$ and $70 \mathrm{~N}$ normal breast epithelial cell strains and 21NT, 21PT, 21MT-2, and $21 \mathrm{MT}-1$ breast tumor cell lines were compared by $\mathrm{DD}$. When primer pair OPAl/ $\mathrm{T}_{12} \mathrm{MG}$ was used, a cDNA of 160 base pairs (bp) appeared as a strong band in the $76 \mathrm{~N}$ lane, was weaker in $70 \mathrm{~N}, 21 \mathrm{NT}, 21 \mathrm{PT}$, and $21 \mathrm{MT}-2$, but was absent in the $21 \mathrm{MT}-1$ highly invasive tumor cell line (Fig. 1A). This band was excised from the $76 \mathrm{~N}$ lane, amplified by PCR, and the resulting $160 \mathrm{bp}$ PCR product was ${ }^{32} \mathrm{P}$-labeled and hybridized to a Northern blot (Fig. 1B). A transcript of $0.6 \mathrm{~kb}$ was detected, which was highly expressed in $76 \mathrm{~N}$, somewhat lower in $70 \mathrm{~N}$, was still lower in $21 \mathrm{NT}, 21 \mathrm{PT}$, and 21MT-2, and was completely absent in the highly invasive $21 \mathrm{MT}-1$ breast tumor cell line. When the partial cDNA obtained from DD was cloned and sequenced, it was found to be identical to the CDNA encoded by the SPR1 gene $(9,10)$. 


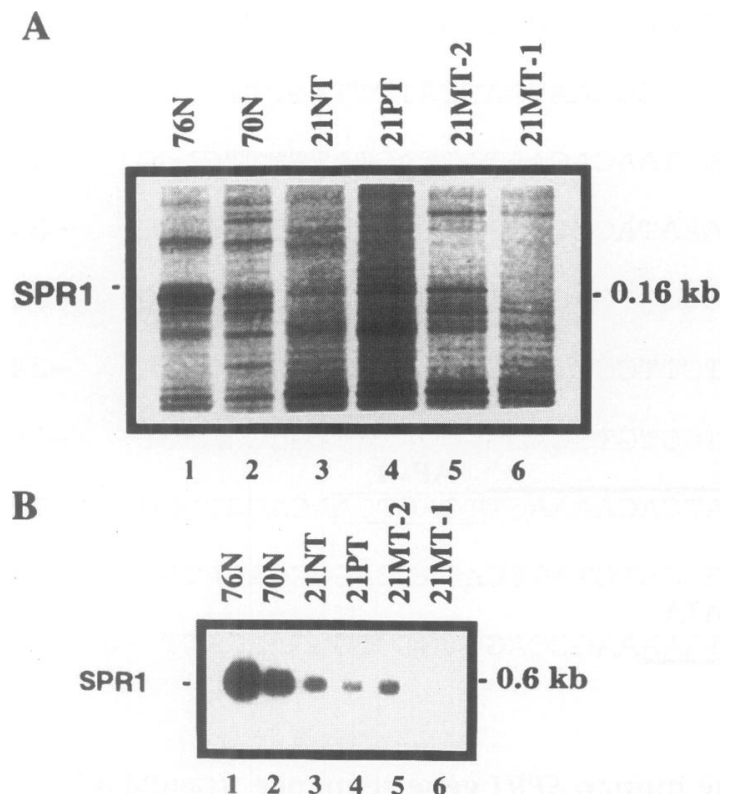

Fig. 1. Identification of the $S P R 1$ gene by differential display on the basis of its down-regulated or absent expression in metastatic tumor cells. (A) Total RNAs from normal human mammary epithelial cell strains $(76 \mathrm{~N}, 70 \mathrm{~N})$ (lanes 1,2), primary (21NT, 21PT) (lanes 3,4), and metastatic breast tumor cell lines (21MT-2, 21MT-1) (lanes 5,6) were compared. The resultant cDNAs were resolved by electrophoresis on a $6 \%$ acrylamide/urea sequencing gel. The position of the SPRI cDNA $(\sim 0.16$ $\mathrm{kb}$ ) is marked. (B) Confirmation of SPRI differential expression pattern by Northern blotting. Total RNAs from normal mammary epithelial cell strains $(76 \mathrm{~N}$, $70 \mathrm{~N}$ ) (lanes 1,2), primary (21NT, 21PT) (lanes 3,4), and metastatic mammary epithelial tumor cell lines (21MT-2, 21MT-1) (lanes 5,6) were compared. Each lane contained $10 \mu \mathrm{g}$ of total cellular RNA. Staining with ethidium bromide showed similar loading of non-degraded RNA in each lane (not shown). The size of the transcript was estimated from molecular size markers run on a parallel lane (not shown).

Expression of SPR 1 mRNA in Normal and Tumor Mammary Epithelial Cells

The expression of SPRI mRNA in normal and tumor mammary cell lines was analyzed by the Northern blot shown in Figure 2. Normal mammary epithelial cell strains such as $76 \mathrm{~N}$, as well as $70 \mathrm{~N}$ and $81 \mathrm{~N}$ (not shown), express the $0.6 \mathrm{~kb}$ $S P R 1$ transcript. One primary tumor cell line (HS-578T) as well as seven metastatic mammary tumor cell lines (MDA-MB-157, MDA-MB-231, MDA-MB-435, MDA-MB-436, BT549, MCF-7, and ZR-75-1) all failed to express the SPRI transcript.

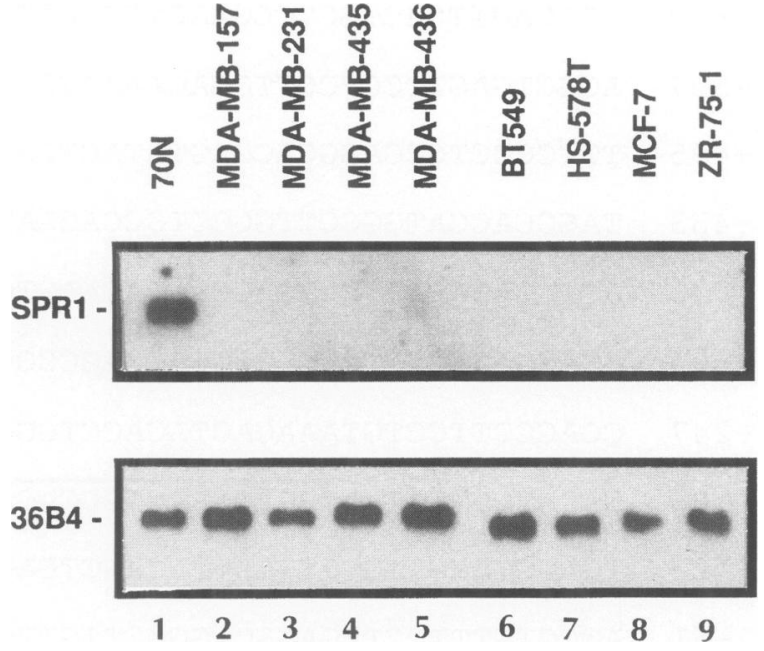

Fig. 2. Northern analysis of SPRI gene expression in normal (70N) and tumor human mammary epithelial cell lines (all others) (top). Each lane contains $20 \mu \mathrm{g}$ of total RNA. The blot was hybridized against a ${ }^{32} \mathrm{P}$-labeled full-length SPRI cDNA probe. Then the blot was stripped and rehybridized to the ribosomal gene 36B4 (22) as an internal loading and transfer control (bottom). The size of the transcript was estimated from molecular size markers run on a parallel lane (not shown).

\section{Cloning of SPR 1 Promoter, Generation of CAT Constructs, and Activity of SPR 1 Promoter in Normal and Tumor Breast Cells}

To analyze the transcription of the SPRI gene, its promoter was cloned upstream of the CAT reporter gene. Since the SPRI promoter sequence was known (16), it could be obtained by PCR from a genomic clone isolated from a human leukocyte library, or directly from genomic DNA isolated from $70 \mathrm{~N}$ cells. The sequence of the PCR product obtained from the leukocyte library displayed a total of 13 discrepancies with the published sequence (16). The sequence was confirmed by sequencing a PCR product generated from $70 \mathrm{~N}$ genomic DNA. The SPRI promoter sequence obtained with these two different templates matched exactly and is shown in Figure 3. Subsequently, pBLCAT2 and pBLCAT3 expression plasmids were used to test the activity of the $S P R I$ promoter. Deletion mutants were prepared to identify promoter regulatory sequences. The pBLCAT2 plasmid contains the minimal herpes virus TK promoter, which has low basal activity in the absence of additional positive regulatory elements, whereas pBLCAT 3 contains neither a promoter nor an enhancer (30). A CAT construct was prepared, which contained the promoter se- 


$$
\begin{aligned}
& \text {-619 CCAGAGTTCACTGCTCCGAACTCTCCTtCACAGACTGAGGTCAGCCTGCCCCTATGTTGTtT -558 } \\
& \text {-557 ACCCTGAGTTCCTCCTTGGAGAAAAGGCTTtTtAGAACCGAAATAATCATtTtAGTTTtTCC -496 }
\end{aligned}
$$

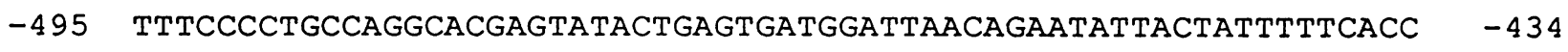

$$
\begin{aligned}
& \text {-433 TAGCCACCATGGCCTtGGCCTCCCAGAATAACCAGAAATACCTATTGTTTAGCTCTACATCC -372 } \\
& \text {-371 ACTtCATATATTAAACAGCCCTACAAGTGTCACCTGTGCTGAGGATtAGACTCTtCCAGAAG -310 } \\
& \text {-309 AtAGGACAGTtTCTGGTTCCAGCAGCCCCAGAATGTCTTCCTTCTCTCTCTTtCAGCCCACA -248 } \\
& \text {-247 CCACCCTTCCTGTAAACACtACACCTGGGAGCAAAGGGTGTTCAGGGGGATAAAGCCCAGGT - } 186 \\
& \text {-185 GACATCCTTGTCAGACAGCAAGTGCCACAAGTTTCATCACAAAAGTTGAGTCAACAGGTGGG }-124
\end{aligned}
$$

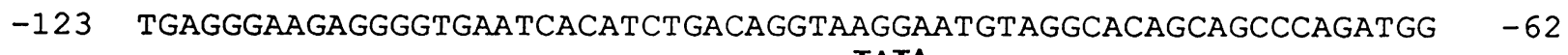

$$
\begin{aligned}
& \text {-61 ATCCTGTTTCCTTGAGGCAGGGCTTGTTCCATGCATAAAAAGCCAGTTGGCTGGGAACACT - } 1 \\
& 1 \text { ACCACCAGTTCTAAG } 15
\end{aligned}
$$

Fig. 3. Nucleotide sequence of the promoter region of the human $S P R 1$ gene sequence. (GenBank ${ }^{\mathrm{TM}}$ / EMBL accession number: AF079516; previously published sequence: M84757). The putative transcription start site is numbered 1. The TATA box is underlined. The AP-1 transcription factor binding site is boxed. The sequence -178 to -139 , where the repressor was localized, is indicated by a boldface line.
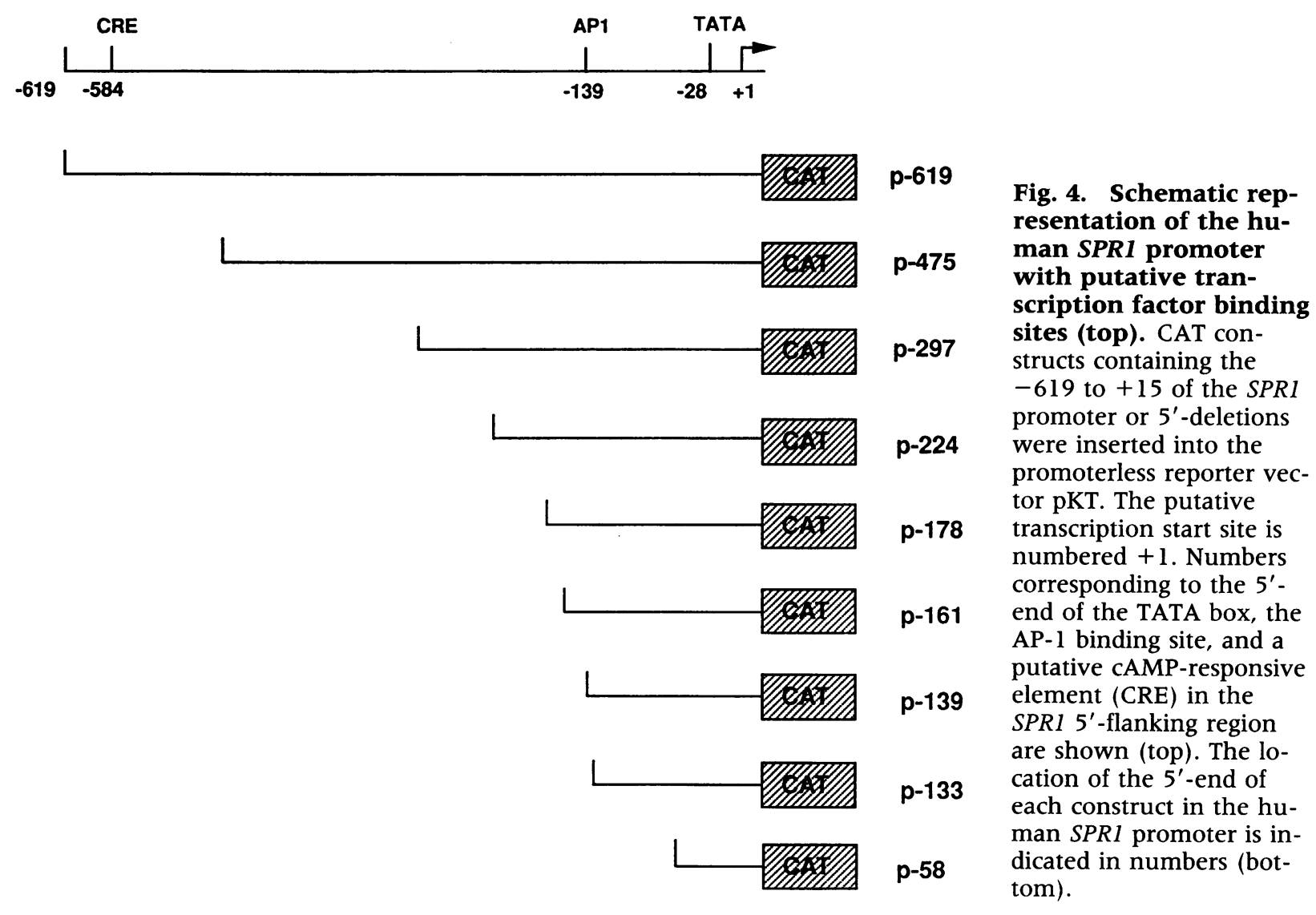

quence generated from the leukocyte library. For promoter analysis, $5^{\prime}$ deletion constructs $(-619$, $-475,-297,-224,-178,-161,-139,-133$, and -58 ) were generated by cloning the corresponding promoter fragments upstream of the CAT reporter gene (Fig. 4). 
A

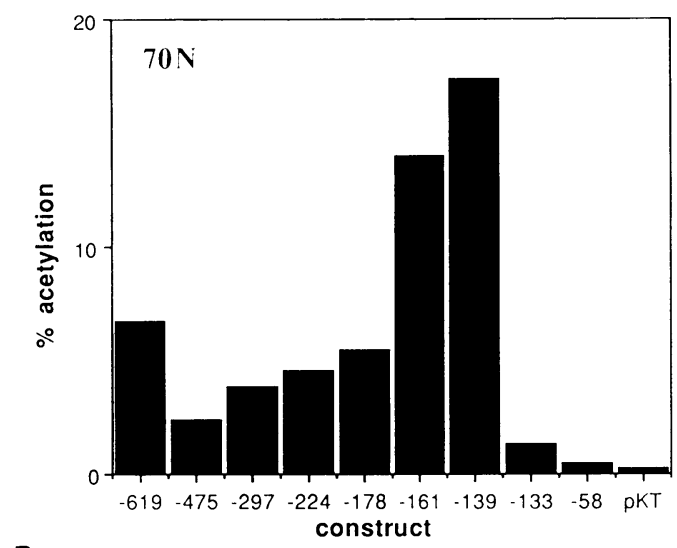

B

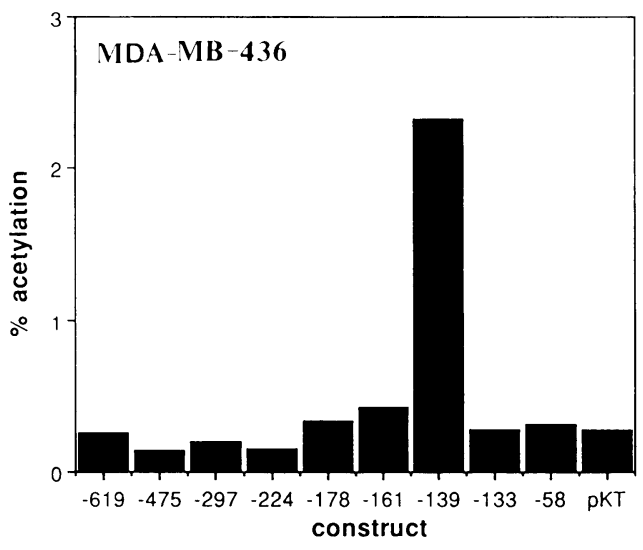

Fig. 5. Deletion analysis of the $S P R I$ promoter. pKTCAT constructs were transfected into $70 \mathrm{~N}$ normal breast cells (A) and MDA-MB-436 breast tumor cells (B). The results were normalized for differences in transfection efficiencies among different cell lines by $\mathrm{co}$-transfecting a $\beta$-Gal expression vector and normalizing for $\beta$-Gal activity. CAT assays were performed on amounts of extracts giving equal activity. Results are typical of triplicate experiments.

To determine whether the promoter fragment $(-619$ to +15$)$ is sufficient for transactivation in cells where the endogenous message is produced and whether it lacks activity in cells where the endogenous message is absent, the sequence -619 to +15 of the SPRI promoter was inserted into the promoterless CAT vector pKT (p-619) and transfected into various normal and tumor cell lines. The result of a typical experiment is shown in Figure $5 \mathrm{~A}$. The $70 \mathrm{~N}$ cells, which express a high amount of SPRI mRNA, produced 5\% acetylation, whereas $21 \mathrm{NT}$ and $21 \mathrm{MT}-2$ cells, which express lower SPRI mRNA levels, produced $1 \%$ and $1.5 \%$ acetylation, respectively (data not shown). However, tumor cell lines MDA-MB-436 (Fig. 6B), and MDA-MB-231, MDA-MD-435 (data not shown), which express no endogenous mRNA, produced activities comparable to the control vector. Therefore, it can be concluded that the -619 to +15 promoter fragment is sufficient for SPRI transactivation in cells that produce some amount of SPRI mRNA, but lacks activity in cells with no detectable SPR1 mRNA. Furthermore, these results suggest that the inactivation of $S P R I$ expression in tumor cells likely occurs by a transcriptional mechanism.

\section{Determination of Putative Regulatory Elements in the SPR I Promoter}

The 5'-deletion constructs shown in Figure 4 were transfected into $70 \mathrm{~N}$ cells and CAT activity was determined. Results of a typical experiment are shown in Figure 5A. Transfection of $70 \mathrm{~N}$ cells with the p-619, p-475, p-297, p-224, and p-178 CAT constructs resulted in acetylation levels ranging from $2 \%$ to $7 \%$, significantly higher than the activity of the promoterless construct. The minor variations initially seen between these constructs were not reproduced when the experiment was repeated twice (data not shown). Transfection of the p-161 and p-139 constructs, however, resulted in markedly higher CAT activity, with acetylation levels of $14 \%$ and $18 \%$, respectively. However, low acetylation of $1 \%$ was observed upon transfection of the p-133 construct, while transfection of the p-58 construct resulted in $0.3 \%$ acetylation. The increase in activity observed with the p-161 and p-139 constructs, compared to the p-178 construct, suggests the presence of an inhibitory element located between -178 and -139 . The sharp drop in activity between the p-139 and p-133 constructs suggests the presence of a positive enhancer element located between -139 and -133 . Our data presented below suggest that the enhancer element, which is required for high levels of SPRI transcription, is very likely the AP- 1 binding site (TGAGTCA), which lies between -139 and -133 .

Are These Regulatory Elements Involved in Downregulation of SPR I Expression in Tumor Cells?

To determine whether the identified inhibitory element located between -178 and -139 and the positive enhancer element located between -139 and -133 are involved in the down-regulation of SPRI expression in tumor cells, the $5^{\prime}$ deletion constructs were transfected into the MDA-MB-436 breast tumor cell line. As seen in Figure 5B, transfection of MDA-MB-436 with 
A

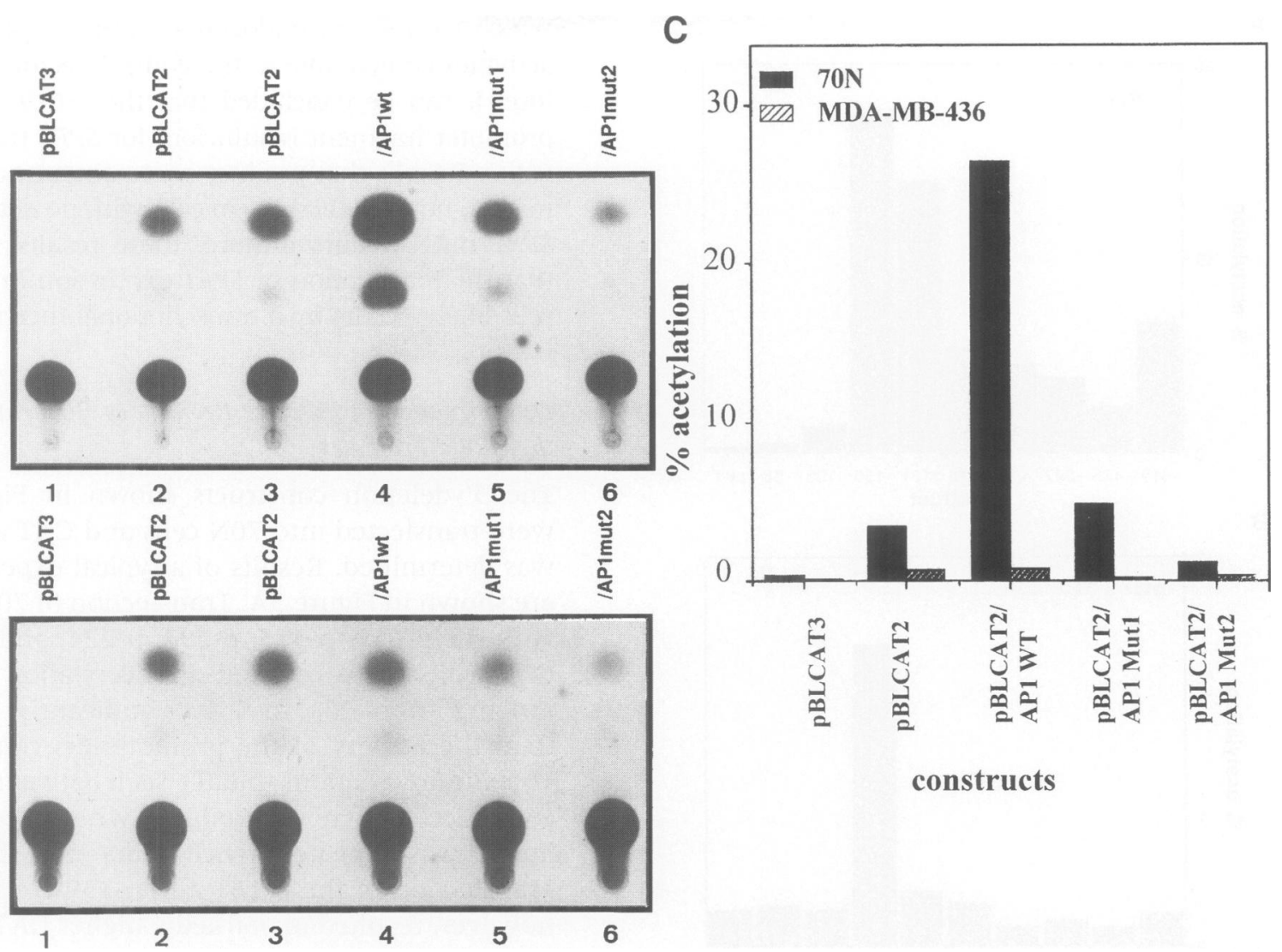

Fig. 6. An intact AP-1 site is required for enhancement of $S P R 1$ promoter activity. CAT assays were performed in 70N normal breast cells (A) and MDA-MB-436 breast tumor cells (B) and the percentage of conversion of $\left[{ }^{14} \mathrm{C}\right]$ chloramphenicol to the acetylated form was measured. Values obtained from counting spots in a scintillation counter are shown (C). CAT constructs were transfected containing wild-type AP-1 (lane 4), and mutant AP-1 with two nucleotide changes (lane 5), or with changes in all seven nucleotides of AP-1 (lane 6). The pBLCAT3 promoterless vector and the pBLCAT2 vector with the TK promoter were transfected as negative controls (lanes $1-3)$. Extracts of $15 \beta$-Gal units were assayed for CAT activity. Results are typical of triplicate experiments.

the p-619, p-475, p-297, p-224, p-178, and $\mathrm{p}-161$ constructs gave acetylation values of $0.1 \%$ to $0.35 \%$, similar to the promoterless vector control. However, when the p-139 construct was transfected into MDA-MB-436 tumor cells, acetylation of $2.3 \%$ was observed, which suggests that an inhibitory element is located between -178 and -139 , in the same region as that found for $70 \mathrm{~N}$ cells. When MDA-MB-436 tumor cells were transfected with the p-133 or p-58 constructs, $0.2 \%$ acetylation was observed again. These results suggest that the AP-1 regulatory element located between -139 and -133 acts as a weak enhancer of transactivation in MDA-MB436 breast tumor cells, although it was shown to act as a much stronger enhancer in $70 \mathrm{~N}$ normal mammary epithelial cells. Similarly, AP-1 has a weak enhancing activity in ZR-75-1 and MCF-7 breast tumor lines (data not shown).
AP-1 Element Acts as an Enhancer in Normal Cells but Not in Tumor Cells

Subsequently, the hypothesis was tested that the AP-1 binding site acts as an enhancer in normal cells but not in tumor cells. Basal AP-1-dependent transactivating activity was measured by cloning oligonucleotides containing the wild-type AP-1 sequence of SPRI upstream of the enhancerless TK promoter in the pBLCAT2 vector. Similarly, two mutant AP-1, with either two nucleotide changes (APl mut1), or all seven changes in the AP-1 site (AP1 mut2) were cloned. The promoterless pBLCAT3 construct produced no activity upon transfection in 70N cells, whereas pBLCAT2 with CAT driven by the TK promoter produced $2.5 \%$ acetylation (Fig. 6A,C). However, the construct containing a wild-type AP- 1 site upstream of the TK promoter yielded a large stimulation of CAT 


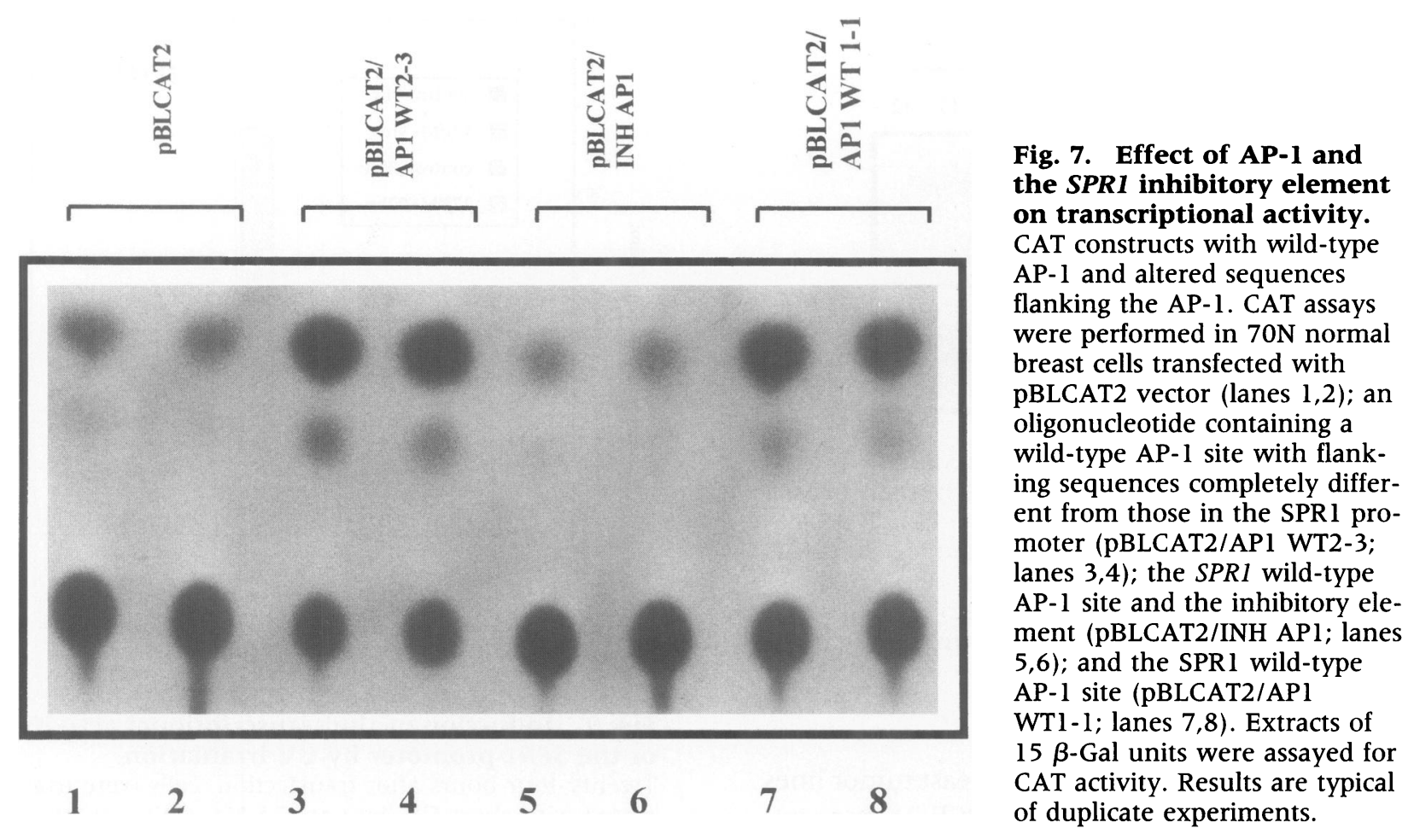

activity (27\% acetylation). This stimulation was not seen with the constructs containing mutations in the AP-1 site. The pBLCAT2/AP-1 mutl construct, with two mutations, gave $3 \%$ acetylation, whereas the pBLCAT2/AP-1 mut2 construct, with all seven positions in AP-1 mutated, gave only $1 \%$ acetylation (Fig. 6C). To test whether the sequences flanking the AP-1 site play a putative role in the stimulation of CAT activity, an oligonucleotide containing the wildtype AP-1 site with completely different flanking sequences was transfected into $70 \mathrm{~N}$ cells. This construct (pBLCAT2/AP-1 WT2-3) produced an 8-fold stimulation of CAT activity compared to pBLCAT2 (Fig. 7, lanes 3,4), which is comparable to the 10-fold stimulation obtained with the oligonucleotide containing wild-type AP-1 and flanking sequences as in the SPR1 gene (pBLCAT2/APl WT1-1) (Fig. 7, lanes 7,8). Therefore, it was concluded that the wild-type AP- 1 site acts as a strong enhancer in $70 \mathrm{~N}$ cells. Furthermore, the flanking sequences surrounding the AP-1 sequence are of minor importance in mediating this enhancing effect. Moreover, in normal $70 \mathrm{~N}$ cells, the inhibitory element $(-178$ to -139 ) can suppress the transcriptional activity of a wild-type AP-l site, as in the construct pBLCAT2/INH AP-1 (Fig. 7, lanes 5,6), which contains the inhibitor upstream of AP-1, like the $S P R I$ promoter.
We sought to determine whether the AP-1 site can act similarly in tumor cells by transfecting the same constructs into MDA-MB-436 tumor cells in which CAT activity was determined (Fig. 6B). The pBLCAT3 construct produced only $0.1 \%$ acetylation, while pBLCAT2 produced $0.5 \%$. Similarly, the construct containing wildtype AP- 1 resulted in no increase in CAT activity ( $0.5 \%$ acetylation) and constructs having mutant AP-1 sites resulted in further reduction of CAT activity (0.1\% acetylation) (Fig. 6C). Therefore, in MDA-MB-436 cells the AP-1 site of SPRI does not act as an enhancer for the heterologous TK promoter.

\section{Up-regulation of SPR 1 Expression in 21MT-2 Tumor Cells by UV Irradiation}

Since the SPRI mRNA was originally identified as being stimulated by short-UV light in keratinocytes $(9,10)$, we investigated whether UV irradiation could likewise stimulate expression of the SPRI message in breast tumor cells. When $21 \mathrm{MT}-2$ cells were irradiated with $25 \mathrm{~J} / \mathrm{M}^{2}$ short-UV light, a reproducible induction of SPRI mRNA was observed, which reached a maximum at $6 \mathrm{hr}$ post-UV treatment (data not shown). Figure 8 shows the result of a doseresponse experiment. The maximum stimulation of SPRI expression was observed with a dose of 


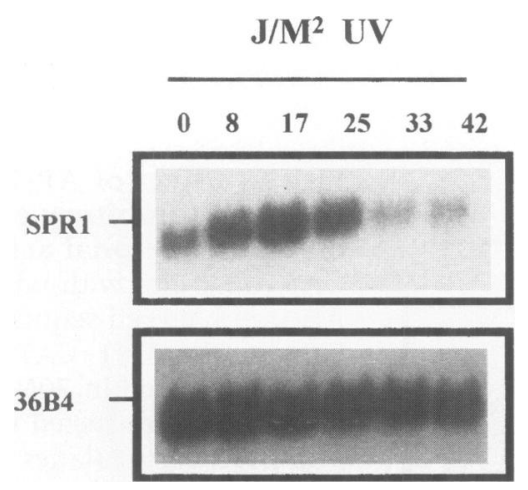

Fig. 8. Northern blot analysis of SPRI induction by UV irradiation of $21 \mathrm{MT}-2$ human breast tumor cells. Cells were irradiated with increasing doses of short-UV light. Each lane contains $20 \mu \mathrm{g}$ of total RNA. The blot was hybridized with a $0.6-\mathrm{kb}$ $S P R 1$ cDNA probe (top) and 36B4 (22) was used as an internal loading and transfer control (bottom).

$17 \mathrm{~J} / \mathrm{M}^{2}$. However, when other breast tumor lines (ZR-75-1, MDA-MB-436, and MCF-7) were examined $6 \mathrm{hr}$ after UV treatment with 17 or 35 $\mathrm{J} / \mathrm{M}^{2}$, no SPRl message could be detected in either case (data not shown). These results suggest that transcriptional activity can be stimulated by UV to up-regulate $S P R I$ in cells that produce some amount of SPRI message. Cells that produce no detectable $S P R I$ message probably have a blockage in SPRI gene expression that cannot be overriden by UV treatment.

Up-regulation of SPR I Expression by UV Treatment Is Mediated by a Transcriptional Mechanism

To elucidate whether UV treatment up-regulates $S P R 1$ expression by a transcriptional mechanism, 21MT-2 cells were transfected with either of two SPRI promoter-driven CAT constructs (pKTSPR1-647 or pKTSPRI-141) or with pCMV$\mathrm{CAT}$, and $16 \mathrm{hr}$ later they were UV-treated at a dose of $17 \mathrm{~J} / \mathrm{M}^{2}$. CAT assays were performed 9 or $32 \mathrm{hr}$ after UV irradiation. When the pKTSPRI647 plasmid was transfected, a small increase in the transcriptional activity was observed after 9 $\mathrm{hr}$, which became more prominent after $32 \mathrm{hr}$, with acetylation levels of $10 \%$ (Fig. 9, left). Transfection of the pKTSPR1-141 construct and hence, deletion of the inhibitory element resulted in much higher increase in CAT activity, with acetylation levels of $8 \%$ and $23 \%$ after 9 and $32 \mathrm{hr}$, respectively (Fig. 9, middle). This result confirms the presence of an active inhibitor regulating the activity of $S P R I$ promoter in

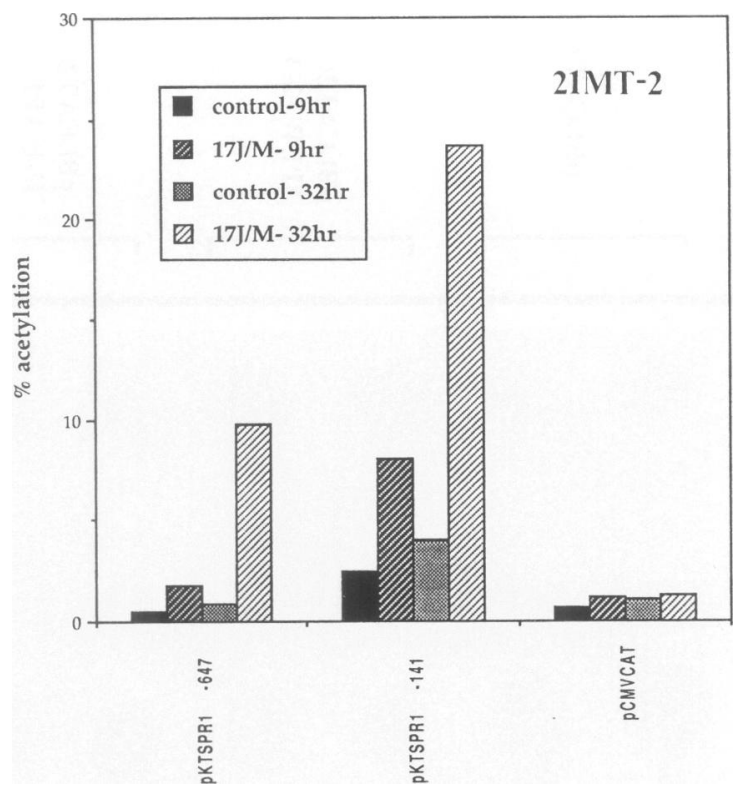

Fig. 9. Induction of the transcriptional activity of the $S P R 1$ promoter by UV irradiation.

Twenty-four hours after transfection, cells were irradiated with short-UV light at $17 \mathrm{~J} / \mathrm{M}^{2}$. CAT activity was measured 9 and $32 \mathrm{hr}$ after UV irradiation. Extracts were normalized for $\beta$-Gal activity. Values for both irradiated cells and non-irradiated controls are typical of triplicate experiments.

both normal and tumor cells. On the other side, transfection of the pCMVCAT control construct containing the strong CMV promoter gave no substantial increase in CAT activity under the same conditions (Fig. 9, right). This result shows that the transcriptional activation observed after UV irradiation is specifically dependent on the pKTSPRI promoter.

\section{Re-expression of SPR I in 21MT-2 Breast} Carcinomas by PMA

Given the presence of an AP-1 consensus site in the $S P R 1$ promoter, we tested whether activation of the PKC signal transduction pathway by PMA would activate the re-expression of $S P R 1$ in 21MT-2 tumor cells. The induction of SPRI mRNA $3 \mathrm{hr}$ after PMA treatment is shown by the Northern blot in Figure 10 and was detected over a period of 3-24 hr. The increase in SPRI mRNA levels was determined from Northern blots by densitometry to be about 10 -fold after $6 \mathrm{hr}$ and more than 40 -fold after $24 \mathrm{hr}$ of PMA treatment. Thus, up-regulation of SPRI expression by PMA was more prominent than its induction by short-UV irradiation. Furthermore, up-regula- 


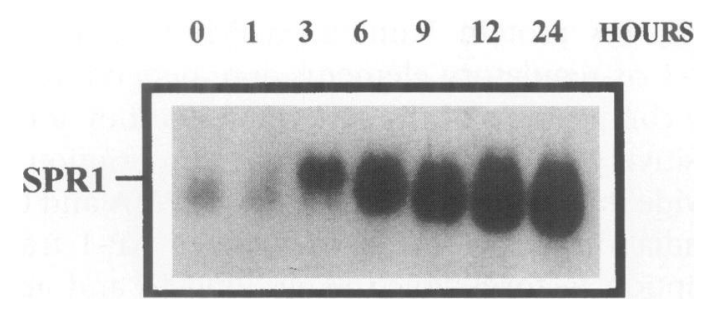

Fig. 10. Northern blot analysis of $S P R 1$ induction by PMA treatment of $21 M T-2$ human breast tumor cells. Each lane contains $20 \mu \mathrm{g}$ of total cellular RNA. The PMA concentration used was $100 \mathrm{ng} / \mathrm{ml}$. The blot was hybridized with a $0.6-\mathrm{kb}$ $S P R I$ CDNA probe. 36B4 (22) was used as an internal loading and transfer control (not shown).

tion of SPRI expression by PMA is primarily transcriptional and is not due to increased stability of the SPRI mRNA, since RNA stability studies showed a $t_{1 / 2}$ of about $12 \mathrm{hr}$ for the SPR1 message in both $76 \mathrm{~N}$ normal and $21 \mathrm{MT}-2$ tumor cells (data not shown).

\section{Induction of SPR I Expression by PMA Is Mediated by AP-1 site}

To elucidate whether PMA up-regulates SPRI by a transcriptional mechanism, 21MT-2 cells were transfected with either of two SPRI promoterdriven CAT constructs or with PCMVCAT and 16 hr later they were stimulated with PMA. Stimulation of SPRI expression was confirmed in each experiment by parallel Northern blot analysis (data not shown). CAT assays were performed 9 or $30 \mathrm{hr}$ after PMA treatment (Fig. 11). When the pKTSPRI-647 plasmid was transfected, a small increase in the transcriptional activity was observed after $9 \mathrm{hr}$, which became more prominent after $30 \mathrm{hr}$ (Fig. 11, left). Deletion of the inhibitory element resulted in a higher increase in CAT activity after $9 \mathrm{hr}$ of PMA treatment observed upon transfection of the pKTSPRI-141 construct (Fig. 11, middle), a result that confirms the presence of an active inhibitor in the SPRI promoter. Finally, transfection of the PCMVCAT control construct gave no substantial increase in CAT activity under the same conditions (Fig. 11, right), showing that the transcriptional activation of $S P R I$ is specifically dependent on the pKTSPRI promoter.

\section{Discussion}

Differential display was applied to the isolation of transcriptionally regulated genes involved in

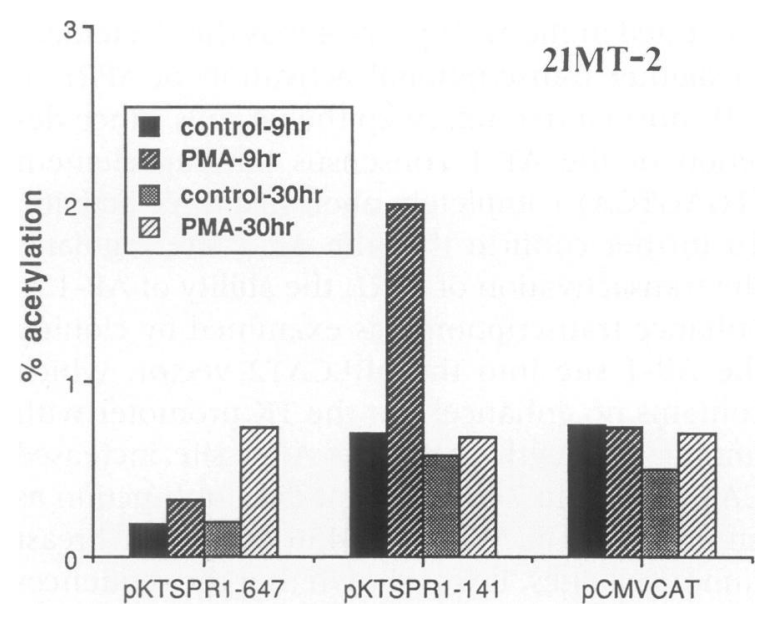

Fig. 11. Stimulation of transcriptional activity of SPR1 promoter by PMA. Twenty-four hours after transfection, 21MT-2 cells were treated with PMA or without PMA (control) for 9 or $30 \mathrm{hr}$. PMA was then removed and CAT activity was measured. Extracts were normalized for $\beta$-Gal activity. Results are typical of triplicate experiments.

mammary carcinogenesis. A known gene, SPRI, was identified as being down-regulated or inactivated in human breast epithelial tumor cell lines. Expression of $S P R 1$ in normal and tumorderived cells is differentially regulated at the transcriptional level. The mechanism of downregulation of SPRI expression in tumor cells has been studied by analyzing the $S P R I$ promoter. The promoter of the SPRI gene was cloned from a human lymphocyte genomic DNA library, and was also amplified by PCR of a genomic DNA template isolated from $70 \mathrm{~N}$ normal breast cells. The promoter fragment -619 to +15 was sufficient for activation of $S P R I$ transcription in normal mammary epithelial cells, however, it was transcriptionally silent in most breast tumor cells, indicating that the reduced or absent expression of SPR1 in breast tumor cells is likely due to its transcriptional down-regulation. In agreement with a mechanism of transcriptional down-regulation of the SPRl gene in breast tumor cells, Southern blot analysis showed uniform patterns of restriction fragments in both normal and tumor cell lines, suggesting that the $S P R I$ gene contains no gross structural alterations in breast tumor cell lines, although point mutations cannot be excluded (data not shown). To identify the functional $S P R 1$ promoter elements, 5' deletion mutants were transiently transfected into $70 \mathrm{~N}$ normal breast cells and several breast tumor cell lines and their relative CAT activity was assayed. An AP-1 binding site was 
identified in the SPRI promoter as the cis element mediating transcriptional activation of $S P R 1$ in $70 \mathrm{~N}$ normal mammary epithelial cells, since deletion of the AP-1 consensus binding element (TGAGTCA) completely abolished CAT activity. To further confirm that the AP-1 site regulates the transactivation of $S P R 1$, the ability of AP- 1 to enhance transcription was examined by cloning the AP-1 site into the pBLCAT2 vector, which contains no enhancer but the TK promoter with minimal strength (24). This AP-1 site increased CAT activity in $70 \mathrm{~N}$ cells, but did not function as an enhancer in MDA-MB-436 and other breast tumor cell lines. It was shown that the sequences flanking the AP-1 site do not affect its promoterenhancing activity. In addition, a major upstream negative regulatory element is located between -178 and -139 in the SPRI promoter, which is active in both normal and tumor cells. It should be noted that an E-26 transformationspecific site (Ets) is present at -55 of the SPRI promoter sequence; however, it gives low CAT activity if AP-1 is deleted (data not shown). Our results demonstrate that down-regulation of $S P R I$ expression in breast tumor cells results from lack of transactivation through AP-1 in combination with a modulated negative regulation through an inhibitory element located between -178 and -138 , which appears more active in tumor cells. This mechanism of aberrant gene expression might be common in tumor cells. For example, transcription of maspin, a tumor-suppressing serpin, is coordinately regulated in prostate cells by a hormone-responsive negative element (HRE) recognized by the androgen receptor that is active in both normal and tumor cells and by an activating Ets binding site, which is inactive in tumor cells, thus, resulting in reduced or absent expression of maspin in prostate tumor cells (31). In breast cells, loss of maspin expression during tumor progression results from the absence of transactivation through the Ets and AP-1 sites (32).

It was shown that loss of SPRI expression can be restored in breast tumor cells by PMA treatment and by UV irradiation. However, expression of SPRI could be stimulated by PMA and UV irradiation only in breast tumor cell lines in which $S P R 1$ is down-regulated, e.g., $21 \mathrm{MT}-2$, but not in tumor cell lines in which the SPRI message is totally absent, e.g., MCF7. PMA is an activator of the PKC signal transduction pathway (33). The PKC pathway initiates a phosphorylation cascade that ultimately activates the expression of AP-1 transcription factors, namely c-Jun and $c$-Fos protein families, which bind to the AP-1 cis-regulatory elements and, depending on the composition of the heterodimers they form, positively or negatively regulate transcription of a wide number of target genes (34). PMA and UV irradiation induce the expression of AP-1 transcription factors, which likely bind to and activate transcription through the AP-1 site in the $S P R I$ promoter. Induction of AP-1 factors by PMA in $21 \mathrm{MT}-2$ cells was previously shown by our group (35). A rapid increase in c-Jun and c-Fos mRNA levels was observed $1 \mathrm{hr}$ after PMA treatment of 21MT-2 cells, whereas JunD was not induced (35). Untreated 21MT-2 contained little AP-1 binding factor. This transcriptional activation is regulated by phosphorylation of $c$-Jun and $c$-Fos proteins at specific sites (36). PMA treatment of 21MT-2 possibly triggers the kinase involved in phosphorylation of AP-1 factors. For example, PMA induction of the elafin gene in 21MT-2 not only involves induction of $c$-Fos and c-Jun but also depends on phosporylations that activate AP-1 factors through the PKC signal transduction pathway (35).

Previous studies of keratinocyte transformation (37) have demonstrated that AP-1 activity increases as keratinocytes become transformed by 12-o-tetradecanoyl-phorbol-13acetate (TPA) or epidermal growth factor (EGF) stimulation, and that blockage of AP-1 prevents transformation. Similarly, an increase in AP-1 activity was observed when mouse epidermal cells were transformed by $\mathrm{X}$-irradiation (36), while AP-1 is shown to be involved in tumor promoter-induced transformation (38). In contrast, our results support recent studies suggesting that normal human mammary epithelial cells have higher AP-1 DNA binding and transactivating activities than human breast cancer cells, with a progressive decline in AP-1 transactivating activity as cells progress through the carcinogenesis pathway (39). In summary, higher AP-1 activity has been reported for some tumors $(36-38,40)$, whereas lower AP- 1 activity was determined in others $(35,39)$. Therefore, common transcription factors such as AP-1 are activated by tissue-specific signaling pathways and transformation likely occurs via distinct molecular pathways in different cell types. The differences in AP-1 activity in normal and malignant cells may indicate that growth of normal mammary epithelial cells is more dependent on signals mediated by AP- 1 than mammary tumor cells. The reduction of AP-1 activity that occurs 
during transformation of human mammary epithelial cells may also be occurring via other signal transduction pathways only active in tumor cells.

UV radiation activates the expression of a wide variety of genes. Short-wavelength UV, like other extracellular stimuli including growth factors, activates signal transduction events that involve both stress- and mitogen-activated protein kinase cascades (41). Although both SPRI and $S P R 2$ proteins were described as being induced by UV, and a CAT activity enhanced by UV was demonstrated in transfected cells, no UV-responsive consensus elements could be identified in the $5^{\prime}$-flanking region of $S P R 1$ or the three $S P R 2$ genes (42). Since UV quickly activates the expression of c-Fos and c-Jun (43), it possibly acts through the same pathway as PMA, and transactivates the SPRI gene expression through the AP-1 binding site in its promoter. This provides a possible explanation for why only those breast tumor cells that produce some amount of SPRI message can be stimulated by UV to up-regulate $S P R I$ expression. It should be noted that SPRI induction by PMA measured by Northern blots is much higher than the activity measured by CAT assays. Induction of SPRI by PMA may result from a cooperative transactivation through the AP-1 and putative unidentified upstream or downstream element(s), missing in CAT constructs. Alternatively, the mechanism of stimulation of $S P R 1$ transcription by PMA could be more complex than its activation induced by UV irradiation, and artificial constructs probably cannot substitute for the native transcriptional machinery.

A major aim of expression genetics in cancer is to specifically correct aberrant gene expression in tumors by the application of therapeutic agents. PMA is toxic; however, induction of SPR1 in breast tumor cells could similarly be induced by drugs acting on the same signal transduction pathway as PMA. If, indeed, genes are coordinately regulated in a network, change in expression of one gene can result in the re-expression of multiple other genes in a coordinate manner, leading to a substantial normalization of tumor phenotypes with obvious therapeutic implications $(1,44)$.

\section{Acknowledgments}

We thank Professor Arthur B. Pardee for helpful suggestions during the course of this work and
Professor A. Papavassiliou for critical reading of the manuscript. Dr. Hatsumi Nagasawa at Harvard School of Public Health is acknowledged for providing the equipment for the UV irradiation experiment.

\section{References}

1. Sager R. (1997) Expression genetics in cancer: Shifting the focus from DNA to RNA. Proc. Natl. Acad. Sci. U.S.A. 94: 952-955.

2. Zou Z, Anisowicz A, Hendrix MJC, et al. (1994) Identification of a novel serpin with tumor suppressing activity in human mammary epithelial cells. Science 263: 526-529.

3. Liang L, Pardee AB. (1992) Differential display of eukaryotic messenger RNA by means of the polymerase chain reaction. Science 257: 967-970.

4. Sager R, Anisowicz A, Neveu M, Liang P, Sotiropoulou G. (1993) Identification by differential display of alpha 6 integrin as a candidate tumor suppressor gene. FASEB J. 7: 964-970.

5. Sager R, Sheng S, Anisowicz A, et al. (1994) RNA genetics of breast cancer: Maspin as a paradigm. Cold Spring Harb. Symp. Quant. Biol. 59: 537-546.

6. Sotiropoulou G, Anisowicz A, Sager R. (1997) Identification, cloning and characterization of cystatin $M$, a novel cysteine proteinase inhibitor, down-regulated in breast cancer. J. Biol. Chem. 272: 903-910.

7. Anisowicz A, Sotiropoulou G, Stenman G, Mok SC, Sager R. (1996) A novel protease homolog differentially expressed in breast and ovarian cancer. Mol. Med. 2: 624-636.

8. Zhang L, Zhou W, Velculescu VE, et al. (1997) Gene expression profiles in normal and cancer cells. Science 276: 1268-1272.

9. Kartasova T, van de Putte P. (1988) Isolation, characterization, and UV-stimulated expression of two families of genes encoding polypeptides of related structure in human epidermal keratinocytes. Mol. Cell. Biol. 8: 2195-2203.

10. Kartasova T, Van Muijen GNP, van Pelt-Heerschap H, van de Putte P. (1988) Novel protein in human epidermal keratinocytes: Regulation of expression during differentiation. Mol. Cell. Biol. 8: 2204-2210.

11. Gibbs S, Fijneman R, Wiegant J, Van Kessel G, van de Putte P, Backendorf C. (1993) Molecular characterization and evolution of the SPRR family of keratinocyte differentiation markers encoding small proline-rich proteins. Genomics 16: 630-637.

12. Lohman FP, Medema JK, Gibbs S, Ponec M, van de Putte P, Backendorf C. (1997) Expression of the SPRR cornification genes is differentially af- 
fected by carcinogenic transformation. Exp. Cell Res. 231: 141-148.

13. Tesfaigzi J, An G, Wu R, Carlson DM. (1995) Two nuclear proteins in tracheal epithelial cells are recognized by antibodies specific to a squamous differentiation marker, spr1. J. Cell. Physiol. 164: 571-578.

14. Tesfaigzi J, Carlson DM. (1996) Expression of the sprl gene in cultured tracheal epithelial cells and its regulation by retinoids before and after confluence. J. Cell. Physiol. 166: 480-486.

15. DeMuth JP, Weaver DA, Crawford EL, Jackson CM, Willey JC. (1998) Loss of sprl expression measurable by quantitative RT-PCR in human bronchogenic carcinoma cell lines. Am. J. Respir. Cell Mol. Biol. 19: 25-29.

16. An G, Tesfaigzi J, Chuu Y-J, Wu R. (1993) Isolation and characterization of the human sprl gene and its regulation of expression by phorbol ester and cyclic AMP. J. Biol. Chem. 268: 1097710982.

17. Reddy SPM, Chuu Y-J, Lao PN, Donn J, Ann DK, Wu R. (1995) Expression of human squamous cell differentiation marker, $S P R I$, in tracheobronchial epithelium depends on JUN and TRE motifs. J. Biol. Chem. 270: 26451-26459.

18. Band V, Zajchowski D, Swisshelm K, et al. (1990) Tumor progression in four mammary epithelial cell lines derived from the same patient. Cancer Res. 50: 7351-7357.

19. Band V, Sager R. (1989) Distinctive traits of normal and tumor-derived human mammary epithelial cells expressed in a medium that supports long-term growth of both cell types. Proc. Natl. Acad. Sci. U.S.A. 86: 1249-1253.

20. Feinberg AP, Vogelstein B. (1983) A technique for radiolabeling DNA restriction endonuclease fragments in high specific activity. Anal. Biochem. 132: 6.

21. Altschul SF, Gish W, Miller W, Myers EW, Lipman DJ. (1990) Basic local alignment search tool. $J$. Mol. Biol. 215: 403-410.

22. Masiakowski P, Breathnach R, Bloch J, Gannon F, Krust A, Chambon P. (1982) Cloning of cDNA sequences of hormone-regulated genes from the MCF-7 human breast cancer cell line. Nucl. Acids Res. 10: 7895-7903.

23. Sambrook J, Fritsch EF, Maniatis T. (1989) Molecular Cloning. A Laboratory Manual. Cold Spring Harbor Laboratory Press, Cold Spring Harbor, NY.

24. Sassone-Corsi P, Verma IM. (1987) Modulation of c-fos gene transcription by negative and positive cellular factors. Nature 326: 507-510.

25. Anisowicz A, Messineo M, Lee S, Sager R. (1991) An NF- $\kappa$ B-like transcription factor mediates IL-1/ TNF- $\alpha$ induction of gro in human fibroblasts. J. Immunol. 147: 520-527.

26. Graham FL, van der Eb AJ. (1973) Transformation of rat cells by DNA of human adenovirus 5. Virology 54: $536-539$.

27. Fridovich-Keil JL, Gudas JM, Dou Q-P, Bouvard I Pardee AB. (1991) Growth-responsive expression from the murine thymidine kinase promoter: $\mathrm{Ge}$ netic analysis of DNA sequences. Cell Growth Differ. 2: 67-76.

28. Gorman CM, Moffat LF, Howard BH. (1982) Recombinant genomes which expressed chloramphenicol acetyl transferase in mammalian cells. Mol. Cell. Biol. 2: 1044-1057.

29. Chan GL, Little JB. (1976) Induction of oncogenic transformation in vitro by ultraviolet light. Nature 264: 442-444.

30. Luckow B, Schutz G. (1987) CAT construction with multiple unique restriction sites for the functional analysis of eukaryotic promoters and regulatory elements. Nucl. Acids Res. 15: 5490.

31. Zhang M, Magit D, Sager R. (1997) Expression of maspin in prostate cells is regulated by a positive Ets element and a negative hormonal responsive element site recognized by androgen receptor. Proc. Natl. Acad. Sci. U.S.A. 94: 974979.

32. Zhang M, Maass N, Magit D, Sager R. (1997) Transactivation through Ets and Apl transactivation sites determines the expression of the tumorsuppressing gene Maspin. Cell Growth Differ. 8: 179-186.

33. Sutherland JA, Cook A, Bannister AJ, Kouzarides T. (1992) Conserved motifs in Fos and Jun define a new class of activation domains. Gene Dev. 6: 1810-1819.

34. Halazonetis TD, Georgopoulos $\mathrm{K}$, Greenberg ME, Ledr P. (1988) c-Jun dimerizes with itself and with c-Fos, forming complexes of different DNA binding affinities. Cell 55: 917-924.

35. Zhang M, Magit D, Pardee AB, Sager R. (1997) Re-expression of elafin in 21MT2 breast carcinomas by phorbol 12-myristate 13-acetate (PMA) is mediated by the Apl site in the elafin promoter. Cancer Res. 57: 4631-4636.

36. Binetruy B, Smeal T, Karin M. (1991) Ha-ras augments c-Jun activity and stimulates phosphorylation of its activation domain. Nature 351: 122-127.

37. Dong Z, Birrer MJ, Watts RG, Matrisian LM, Colburn NH. (1994) Blocking of tumor promoterinduced AP-1 activity inhibits induced transformation in JB6 mouse epithermal cells. Proc. Natl. Acad. Sci. U.S.A. 91: 609-613.

38. Li J-J, Westergaard C, Ghosh P, Colburn NH. (1997) Inhibitors of both nuclear factor- $\kappa B$ and activator protein-1 activation block the neoplastic transformation response. Cancer Res. 57: 35693576.

39. Smith LM, Birrer MJ, Stampfer MR, Brown PH. (1997) Breast cancer cells have lower activating protein 1 transcription factor activity than normal 
mammary epithelial cells. Cancer Res. 57: 30463054.

40. Domann FE Jr, Levy JP, Finch JS, Bowden GT. (1994) Constitutive AP-1 DNA binding and transactivating ability of malignant but not benign mouse epithermal cells. Mol. Carcinogen. 9: 61-66.

41. Tyrrell RM. (1996) Activation of mammalian gene expression by the UV component of sunlight-from models to reality. BioEssays 18: 139148.

42. Gibbs S, Lohman F, Teubel $W$, van de Putte $P$, Backendorf C. (1990) Characterization of the hu- man spr2 promoter: Induction after UV irradiation or TPA treatment and regulation during differentiation of cultured primary keratinocytes. $\mathrm{Nucl}$. Acids Res. 18: 4401-4407.

43. Buscher $M$, Rahmsdorf HJ, Litfin $M$, Karin $M$, Herrlich P. (1988) Activation of the c-fos gene by UV and phorbol ester: Different signal transduction pathways converge to the same enhancer element. Oncogene 3: 301-311.

44. Zhang M, Martin KJ, Sheng S, Sager R. (1998) Expression genetics: A different approach to cancer diagnosis and prognosis. Trends Biotechnol. 16: $66-71$. 